\title{
AGEING POPULATION AND EXTERNAL DEBT: AN EMPIRICAL INVESTIGATION
}

\author{
Nur Hayati ABD RAHMAN (D), Shafinar ISMAIL (D), \\ Abdul Rahim RIDZUAN (D) \\ Faculty of Business and Management, Universiti Teknologi MARA, Melaka, Malaysia
}

Received 30 September 2019; accepted 22 May 2020

\begin{abstract}
A rise in the ageing population is the current demographic challenge which is capable of pressuring the government to borrow more external funds in order to support domestic needs. This study aims to investigate the effects of the external debt of 36 upper-middle-income economies from 2000 to 2017 due to the increase in the ageing population. This study employed the system Generalised Method of Moments (GMM), where it revealed that the ageing population could increase the level of external debt if the population aged 65 and above was used as a proxy to represent the ageing population. However, the results were insignificant when the proxy was changed to the old-age dependency ratio. It illustrated that the increase in external debt occurs due to the increase in the population aged 65 and above because the government has to allocate more funds for healthcare, age-friendly infrastructure, social security and pensions. However, the dependency of the older people on government is minimal because of their long-term savings. Hence, the old-age dependency ratio has an insignificant relationship with the external debt level. For future research, it is suggested that the impact of the ageing population can be investigated on the domestic debt level.
\end{abstract}

Keywords: ageing population, external debt, GMM, upper-middle-income economies, old-age dependency, population ages 65 and above, healthcare, pensions, social security.

JEL Classification: E62, H63, J14.

\section{Introduction}

The two main demographic challenges globally at the current moment are the rise in the ageing population and a decline in the fertility rate (Fu et al., 2020; Mao et al., 2020). As for the former, the dependency on labors is expected to decline as technology is taking over the industry and is being accepted by many firms to replace manpower in their production lines. The change is driven by the need for artificial intelligence, robotics, machine learning and internet of other things. These elements, which are within the fourth industrial revolution, necessitates countries to inject more capital into some the critical areas. The areas include

\footnotetext{
${ }^{\star}$ Corresponding author. E-mail: nurhayati.uitmt@gmail.com
} 
research and development, innovation, human capital investment and infrastructure development. These development expenditures are highly essential for future sustainable growth. However, an increase in the ageing population might additionally lead to a rise in the government' operating expenses.

Therefore, in order to accommodate higher demand for funds, the governments can generate funds from three primary sources, namely taxation, money creation and public debt (Ghosh \& Ghosh, 2008). However, money creation is not preferred as it creates inflation. Similarly, tax is also less favorable as it imposes an excess burden to the public by limiting their purchasing power and by distorting the levels of consumptions and investments in an economy (Barro, 1979). Hence, the public debt falls in place, especially when the government is facing fiscal imbalances. Between the types of debts, domestic and external, the latter is more vulnerable. Countries with a high level of external debt should be able to confront the global economic turbulences because of their ability to repay the debt is highly dependent on the global economic situation.

Theoretically, the factors determining the level of external debt for a country are the average anticipated rate of inflation, the real values of the temporary movement of the government expenditures and the national income (Barro, 1979). Empirically, vast literature has discussed the determinants of external debt by including other variables such as government revenues (Mensah et al., 2017; Waheed, 2017), investments (Sadik-Zada \& Gatto, 2019; Waheed, 2017; Mohd Daud \& Podivinsky, 2012), current account (Waheed, 2017), reserve (Waheed, 2017), resource prices (Waheed, 2017) and primary balance (Hasanov \& Cherif, 2012; Pirtea \& Nicolescu, 2012; Poghosyan, 2018). However, the existing empirical literature does not conclusively highlight the roles of the ageing population in influencing the level of public debt. This paper attempts to fill in the gaps by providing some empirical evidence on how the ageing population affects the public debt in the upper-middle-income economies (UMIE). It is essential to address this issue as the government's burden is expected to increase when the economy is facing an increased number of the ageing population. The findings from this study might be helpful for governments and policymakers to redesign their existing policies by taking into account the impacts of the ageing population on the fiscal imbalances.

The organization of this paper is as follows. The next section discusses in brief the literature review of relevant studies. Follow suit is the third section that introduces the methodology, research framework, data and econometric models. The fourth section presents the findings and discussion, while the fifth section concludes the study and presents relevant policy implications.

\section{Literature review}

\subsection{Theoretical review}

The public debt theory by Barro (1979), and extended by Mensah et al. (2017) can be used as a starting point to understand how ageing population affects the public debt level. The theory claims that the government have to incur public debt due to three reasons namely (1) the uses of funds, (2) the sources of funds, and (3) the policy objectives. The use of funds is primarily 
to finance government expenditures. Meanwhile, the sources of funds can be derived from taxation (Mensah et al., 2017), investment (Sadik-Zada \& Gatto, 2019; Waheed, 2017) and domestic borrowing (Mensah et al., 2017). However, if the government has enough funds to cover its expenditures, the level of external debt is expected to reduce. Finally, the government accumulates higher external debt to achieve the two main policy objectives, namely low inflation and high economic growth. The government is required to inject more funds to support the economy at the time of inflation or to achieve higher economic growth. Hence, the fiscal stimulus by using public debt might be necessary.

In relation to the ageing population, the government is expected to bear a higher financial burden when the number of the ageing population increases. Thus, the uses of funds are expected to increase, thus stimulating higher accumulation of public debt. The government can impose taxes to cover additional costs due to the rise in expenditures related to pensions, transfer payments, etc. However, it is not advisable to do so as it creates a distortionary effect on economic growth. Thus, theoretically, the ageing population will generally increase the government's debt.

\subsection{Empirical review}

Empirically, most of the papers have been focusing on the above-listed variables as theoretically outlined by Barro (1979) and Mensah et al. (2017). There is limited research available on how the ageing population as a demographic variable affects the external debt of countries. The investigation on this matter is crucial as the increase in the ageing population might force the government to spend more on age-friendly infrastructures (Goedl \& Zwick, 2018), pensions (Alonso-Garcia \& Rosado-Cebrian, 2019), medicines and so on. Thus, there is a tendency for the government to borrow more funds from the external market due to the rise in government spending. Excessive spending on the ageing population is not a good move as it might distort the economic growth. It is consistent with the theory of secular stagnation (Jackson, 2019), in which the increase in the ageing population will increase the budgetary pressure of the government. It will lead to economic stagnation because most of the expenditures for the ageing population are under the category of the operating expenditure. Instead, the government should focus on spending in development expenditures (Ono \& Uchida, 2018; Shkolnyk \& Koilo, 2018) since it gives higher benefits and value-added for long-term economic sustainability. The government can concentrate on developing the economy if everyone take charge in taking care of their parents' needs and wants. As discussed in the theory of intergenerational social contract, it is a social obligation of each individual to take care of their parents when they are older (Hillman, 2003). The burden should not be shifted to the government.

Moreover, previous empirical literature was focused on the oil and gas export-import countries (Waheed, 2017), advanced economies (Caruso \& Domizio, 2017; Hasanov \& Cherif, 2012), emerging economies (Poghosyan, 2018), lower-middle-income economies (Mensah et al., 2017) and mixed economies (Benfratello et al., 2018; Sadik-Zada \& Gatto, 2019). UMIE has not received attention in the existing literature. The countries listed within UMIE are worth investigating since they are striving to achieve high-income economies. In order 
to achieve higher income, substantial amounts of capital are needed to boost the economy, especially during the global transformation into the fourth industrial revolution. Hence, the need for external debt is highly relevant to these countries as opposed to domestic debt. High domestic debts tend to crowd-out private investments (Reinhart et al., 2012), thus slowing down the economic growth of the country. Since the UMIE aim to become high-income economies, the economic slowdown is not an option. Thus, external debt is necessary as an engine of growth for UMIE. Therefore, this research investigated the effects of the ageing population on the external debt of the UMIE from 2000 to 2017.

This paper contributes to the existing literature by addressing the following issues. Firstly, the effects of the ageing population on the external debt of the UMIE were investigated. This aspect has not been extensively explored (Goedl \& Zwick, 2018), especially by using external debt and the UMIE as the scopes of settings. Secondly, this paper extends the model of external debt accumulation by Mensah et al. (2017) by integrating total government revenues as one of the independent variables. The previous model by Mensah et al. (2017) only included taxation as the source of government income. The inclusion of other sources of revenues was vital to capture the entirety of the fiscal imbalance apart from tax in the current study. Thirdly, to ensure the goodness of findings, the issues regarding endogeneity were handled accordingly in the estimation model. The robustness tests were also conducted to ensure consistency of the results by testing the debt model with two proxies that represent the ageing population.

The organization of this paper is as follows. Section 2 discusses the framework and methodology used to answer the objective. Section 3 and 4 presents the findings and discussion, respectively, while the last section concludes the study.

\section{Research framework}

The underlying framework of public debt accumulation was derived from Barro's model of public debt (Barro, 1979). In his framework, he stressed the importance of three variables in determining the public debt level, namely (1) average anticipated inflation rate, (2) temporary movement of the government expenditure and (3) national income. Due to the difficulties in measuring the anticipated rate of inflation, Barro has also proven that the long-term interest rate can be a good proxy for the anticipated inflation.

Decades later, the original framework by Barro (1979) was extended by Mensah et al. (2017) by the addition of four other variables (taxation, investment, domestic savings and domestic borrowings) in explaining the determination of external debt. Thus, a total of seven variables were grouped into three components of public debt namely, (1) the uses of funds (government expenditure), (2) the sources of funds (taxation, investment, domestic savings and domestic borrowings), and (3) the policy objectives (inflation and economic growth). In this paper, these variables were regarded as the control variables. Hence, the framework underlying this paper was mainly derived from Barro (1979) and Mensah et al. (2017). The framework was further enhanced by adding the ageing population and interest payments on external debt as additional elements in the model. 


\section{Data, methodology and econometric estimation}

Based on the available data, this study included 36 out of 51 countries within the UMIE. The panel of data comprised of annual data from 2000 to 2017. The choice of these years as a period of study is due to data availability as well as the seriousness of the debt issue among UMIE from the early of 2000. Statistically, 55 percent of the countries under investigation were recorded to accumulate an average external debt of more than 40 percent of the GDP (The World Bank Group, 2018). Besides, given the average percentage of the ageing population to total population is increases across the years, high accumulation of external debt is a serious issue that might hinder the economic growth if it is not properly managed.

Prior to the estimation, three-year non-overlapping averages were calculated for all data to cater to the short-run business cycle fluctuations (Arčabić et al., 2018; Law, 2018; Kim et al., 2017). Since the data has a short time series with a large number of cross-sections, the Generalized Method of Moments (GMM) was employed as an estimation method. The method helps to solve the endogeneity problem that exists in the debt-growth model. On the other hand, the traditional panel data estimators such as Pooled Ordinary Least Square (POLS), fixed effect (FE) and random effect (RE) models are inappropriate due to their inability to solve the problem of endogeneity in short time series (Law, 2018). Thus, the baseline regression based on a dynamic model specification in the GMM is written as follows:

$$
\begin{gathered}
e^{e d e b t_{i t}}=\text { pedebt }_{i, t-1}+\beta a g e_{i t}+\delta X_{i t}+U_{i t} ; \\
X=f(\text { age }, g e, r e v, \text { inv, sav, debt,inf, rgdp, inf }) ; \\
U_{i t}=\mu_{i}+v_{i t},
\end{gathered}
$$

where edebt is the ratio of external debt stock to Gross National Income (GNI), $X$ is the vector of control variable based on Barro (1979) and Mensah et al. (2017), $i$ and $t$ represent the countries and years respectively, while $U_{i t}$ is the error term which consists of unobserved timeinvariant effect $\left(\mu_{i}\right)$ and random disturbance term $\left(v_{i t}\right)$. Besides, the proxy for the ageing population is the ratio of population aged 65 and above against the total population (noted by age1). The old-age dependency ratio was also used as a percentage of the working-age population as another proxy for the ageing population (indicated by age2). These two proxies were used for the robustness test to determine the consistency of the results. All data are in natural logarithm form. The detailed explanation of the variables used in this paper is provided in Table 1.

The $\mu_{i}$ and $v_{i t}$ are independent of each other and among themselves. However, since the $\mu_{i}$ is not varied with time, Arellano and Bond (1991) suggested that the time-invariant effect should be eliminated by first-differencing the above equation. As a result, the fist-difference equation was derived as follows:

$$
\begin{aligned}
& e d e b t_{i t}-e d e b t_{i t-1}=\rho\left(e d e b t_{i, t-1}-e d e b t_{i, t-2}\right)+\beta\left(a g e_{i t}-a g e_{i t-1}\right)+ \\
& \delta\left(X_{i t}-X_{i t-1}\right)+\left(v_{i t}-v_{i t-1}\right) \text {. }
\end{aligned}
$$

GMM solves the endogeneity problem by including the lagged values of the explanatory variables as the instruments (Arellano \& Bond, 1991). The two types of GMM that exist include difference GMM and system GMM. Although both methods include lagged values as 
the instruments, the difference GMM only consists of the difference equation while system GMM consists of both difference and level equations. Nevertheless, system GMM is expected to generate a better estimation relative to the difference GMM as the independent variables become persistent (Blundell \& Bond, 1998). It is because vit in the difference GMM is correlated with the dependent lagged variable $\left(e d e b t_{i, t-1}-e d e b t_{i, t-2}\right)$ that is included as a regressor. Therefore, this paper employed system GMM as it uses moment conditions of lagged levels as instruments for the differenced equation.

Nevertheless, the use of system GMM is subject to two main conditions. Firstly, the additional instruments added in the model must be valid. Hence, the Hansen test of overidentifying restrictions was used to validate the additional instruments (Hansen, 1982). Secondly, the $v_{i t}$ should be free from the second-order autocorrelation. This condition was tested using the Arrelano-Bond test for $\mathrm{AR}(2)$ with a null hypothesis that there is no second-order serial correlation for the disturbance in the equation.

Table 1. Variables used in this study

\begin{tabular}{|c|c|c|c|c|}
\hline No. & Notation & Description of the variable & $\begin{array}{c}\text { Measurement } \\
\text { unit }\end{array}$ & Sources \\
\hline 1 & edebt & External debt stocks to GNI & Percentage & $\begin{array}{l}\text { World Development Indica- } \\
\text { tor (WDI), World Bank }\end{array}$ \\
\hline 2 & l.edebt & $\begin{array}{l}\text { Lag of external debt stocks to GNI } \\
\text { (based on the initial value of the } \\
\text { external debt for each overlapping } \\
\text { three-year period) }\end{array}$ & Percentage & $\begin{array}{l}\text { World Development } \\
\text { Indicator (WDI), World } \\
\text { Bank }\end{array}$ \\
\hline 3 & age 1 & $\begin{array}{l}\text { Ratio of the population ages } 65 \text { and } \\
\text { above against total population }\end{array}$ & Percentage & $\begin{array}{l}\text { World Development Indica- } \\
\text { tor (WDI), World Bank }\end{array}$ \\
\hline 4 & age2 & $\begin{array}{l}\text { Ratio of old age dependency ratio } \\
\text { against working-age population }\end{array}$ & Percentage & $\begin{array}{l}\text { World Development Indica- } \\
\text { tor (WDI), World Bank }\end{array}$ \\
\hline 5 & $g e$ & $\begin{array}{l}\text { General government total } \\
\text { expenditure as a percentage of GDP }\end{array}$ & Percentage & $\begin{array}{l}\text { World Economic Outlook, } \\
\text { International Monetary Fund } \\
\text { (IMF) }\end{array}$ \\
\hline 6 & rev & $\begin{array}{l}\text { General government revenue as a } \\
\text { percentage of GDP }\end{array}$ & Percentage & $\begin{array}{l}\text { World Economic Outlook, } \\
\text { International Monetary Fund } \\
\text { (IMF) }\end{array}$ \\
\hline 7 & inv & $\begin{array}{l}\text { Gross capital formation as a } \\
\text { percentage of GDP }\end{array}$ & Percentage & $\begin{array}{l}\text { World Development Indica- } \\
\text { tor (WDI), World Bank }\end{array}$ \\
\hline 8 & sav & $\begin{array}{l}\text { Gross domestic savings as a } \\
\text { percentage of GDP }\end{array}$ & Percentage & $\begin{array}{l}\text { World Development Indica- } \\
\text { tor (WDI), World Bank }\end{array}$ \\
\hline 9 & debt & $\begin{array}{l}\text { General government gross debt as a } \\
\text { percentage of GDP }\end{array}$ & Percentage & $\begin{array}{l}\text { International Monetary Fund } \\
\text { (IMF) }\end{array}$ \\
\hline 10 & inf & $\begin{array}{l}\text { Annual percentage of inflation } \\
\text { based on consumer prices }\end{array}$ & Percentage & $\begin{array}{l}\text { World Development Indica- } \\
\text { tor (WDI), World Bank }\end{array}$ \\
\hline 11 & $\operatorname{rgdp}$ & Annual growth of real GDP & Percentage & $\begin{array}{l}\text { World Economic Outlook, } \\
\text { International Monetary Fund } \\
\text { (IMF) }\end{array}$ \\
\hline 12 & int & $\begin{array}{l}\text { Interest payments on external debt } \\
\text { as a percentage of GNI }\end{array}$ & Percentage & $\begin{array}{l}\text { World Development Indica- } \\
\text { tor (WDI), World Bank }\end{array}$ \\
\hline
\end{tabular}




\section{Findings and discussion}

Table 2 illustrates the summary statistics for all the variables used in this study. The interest on external debt has the lowest mean of 0.1468 while the ratio of the gross capital formation to GDP as a proxy of the investment recorded the highest mean, with the value of 50.14147. Meanwhile, the ratio of the general government expenditure to GDP scored the lowest standard deviation of 0.2992028 , while the inflation rate measured the highest standard deviation value of 38.20234 .

Table 2. Summary statistics of all variables

\begin{tabular}{|c|c|c|c|c|c|}
\hline Variables & Observation & Mean & Standard Deviation & Minimum & Maximum \\
\hline edebt & 193 & 3.6267 & 0.7949 & 0.3054 & 4.9996 \\
\hline age 1 & 205 & 1.9619 & 0.4622 & 1.1818 & 3.0271 \\
\hline age2 & 205 & 2.3769 & 0.4282 & 1.6657 & 3.4549 \\
\hline ge & 205 & 3.3558 & 0.2992 & 2.4929 & 4.0048 \\
\hline rev & 205 & 3.2687 & 0.3148 & 2.3887 & 3.8830 \\
\hline inv & 190 & 50.1414 & 14.9228 & 0.2565 & 104.8875 \\
\hline sav & 199 & 43.5547 & 31.0919 & 0.0382 & 120.7834 \\
\hline debt & 205 & 3.5507 & 0.6820 & 1.3779 & 5.1776 \\
\hline inf & 203 & 15.0414 & 38.2023 & 0.2964 & 509.8990 \\
\hline rgdp & 205 & 8.1663 & 5.7986 & 0.0305 & 47.8089 \\
\hline int & 193 & 0.1468 & 0.9654 & -4.7405 & 1.9605 \\
\hline
\end{tabular}

Table 3 illustrates the correlation matrix between all variables used in the current study. Among the independent variables, four series were identified to possess correlation values of more than 0.8 namely between ge and $r e v(r=0.929)$ as well as age 1 and age2 $(r=0.9936)$. However, to ensure robust estimation, this study did not include age 1 and age 2 together in the same model to avoid multicollinearity problem.

Table 3. Correlation matrix

\begin{tabular}{|c|c|c|c|c|c|c|c|c|c|c|c|}
\hline & edebt & debt & ge & int & rev & sav & inv & inf & age2 & rgdp & age1 \\
\hline edebt & 1 & & & & & & & & & & \\
\hline debt & 0.4358 & 1 & & & & & & & & & \\
\hline ge & 0.0721 & 0.1495 & 1 & & & & & & & & \\
\hline int & 0.8544 & 0.4107 & 0.034 & 1 & & & & & & & \\
\hline rev & 0.0146 & -0.027 & 0.929 & -0.002 & 1 & & & & & & \\
\hline sav & -0.525 & -0.538 & -0.144 & -0.438 & 0.048 & 1 & & & & & \\
\hline inv & -0.526 & -0.333 & 0.109 & -0.562 & 0.145 & 0.5466 & 1 & & & & \\
\hline inf & -0.147 & -0.134 & 0.082 & -0.055 & 0.042 & 0.124 & 0.2033 & 1 & & & \\
\hline age2 & 0.3662 & 0.0156 & 0.349 & 0.2993 & 0.335 & -0.242 & -0.021 & -0.035 & 1 & & \\
\hline rgdp & -0.121 & -0.319 & -0.148 & -0.102 & -0.057 & 0.2549 & 0.2767 & -0.032 & -0.039 & 1 & \\
\hline age1 & 0.3196 & -0.006 & 0.359 & 0.2481 & 0.348 & -0.199 & 0.0135 & -0.023 & 0.9936 & -0.027 & 1 \\
\hline
\end{tabular}


Table 4. System-GMM results

\begin{tabular}{|c|c|c|c|c|}
\hline Independent Variables & 1 & 2 & 3 & 4 \\
\hline l.edebt & $\begin{array}{c}0.756^{\star * *} \\
(0.013)\end{array}$ & $\begin{array}{c}0.754^{\star * \star} \\
(0.015)\end{array}$ & $\begin{array}{c}0.743^{\star * *} \\
(0.014)\end{array}$ & $\begin{array}{c}0.737^{\star * *} \\
(0.018)\end{array}$ \\
\hline debt & $\begin{array}{c}0.070^{* * *} \\
(0.013)\end{array}$ & $\begin{array}{c}0.077^{\star * *} \\
(0.013)\end{array}$ & $\begin{array}{c}0.084^{\star * *} \\
(0.013)\end{array}$ & $\begin{array}{c}0.080^{\star * *} \\
(0.013)\end{array}$ \\
\hline$g e$ & $\begin{array}{l}0.147^{* *} \\
(0.054)\end{array}$ & & $\begin{array}{l}0.117^{\star *} \\
(0.056)\end{array}$ & \\
\hline int & $\begin{array}{c}0.118^{\star \star *} \\
(0.010)\end{array}$ & $\begin{array}{c}0.124^{\star * *} \\
(0.012)\end{array}$ & $\begin{array}{c}0.119^{\star * *} \\
(0.010)\end{array}$ & $\begin{array}{c}0.134^{\star * \star} \\
(0.011)\end{array}$ \\
\hline rev & & $\begin{array}{c}0.056 \\
(0.056) \\
\end{array}$ & & $\begin{array}{c}0.003 \\
(0.070) \\
\end{array}$ \\
\hline$s a v$ & $\begin{array}{c}-0.002^{\star * *} \\
(0.000)\end{array}$ & $\begin{array}{c}-0.002^{\star * *} \\
(0.000)\end{array}$ & $\begin{array}{c}-0.002^{\star * *} \\
(0.000)\end{array}$ & $\begin{array}{c}-0.002^{* * *} \\
(0.000)\end{array}$ \\
\hline inv & $\begin{array}{l}0.001^{\star} \\
(0.001)\end{array}$ & $\begin{array}{c}0.002^{\star * *} \\
(0.001)\end{array}$ & $\begin{array}{c}0.001 \\
(0.001)\end{array}$ & $\begin{array}{l}0.002^{* *} \\
(0.001)\end{array}$ \\
\hline $\inf$ & $\begin{array}{c}-0.001^{\star \star *} \\
(0.000)\end{array}$ & $\begin{array}{c}-0.001^{\star \star \star} \\
(0.000)\end{array}$ & $\begin{array}{c}-0.001^{\star * *} \\
(0.000)\end{array}$ & $\begin{array}{c}-0.001^{\star * *} \\
(0.000)\end{array}$ \\
\hline $\operatorname{rgdp}$ & $\begin{array}{c}-0.004^{\star * *} \\
(0.001)\end{array}$ & $\begin{array}{c}-0.005^{\star * *} \\
(0.000)\end{array}$ & $\begin{array}{c}-0.004^{\star \star *} \\
(0.001)\end{array}$ & $\begin{array}{c}-0.005^{\star * *} \\
(0.000)\end{array}$ \\
\hline age1 & & & $\begin{array}{l}0.058^{\star *} \\
(0.027)\end{array}$ & $\begin{array}{l}0.063^{\star *} \\
(0.031)\end{array}$ \\
\hline age2 & $\begin{array}{c}0.026 \\
(0.020)\end{array}$ & $\begin{array}{c}0.033 \\
(0.032)\end{array}$ & & \\
\hline Constant & $\begin{array}{c}0.162 \\
(0.165)\end{array}$ & $\begin{array}{l}0.381^{*} \\
(0.192)\end{array}$ & $\begin{array}{c}0.204 \\
(0.177)\end{array}$ & $\begin{array}{l}0.550^{\star \star} \\
(0.218)\end{array}$ \\
\hline Observations & 176 & 176 & 176 & 176 \\
\hline No. of instruments & 49.000 & 41.000 & 49.000 & 41.000 \\
\hline AR1 $p$-value & 0.013 & 0.018 & 0.015 & 0.022 \\
\hline AR2 $p$-value & 0.154 & 0.165 & 0.147 & 0.148 \\
\hline Hansen $p$-value & 0.906 & 0.634 & 0.879 & 0.692 \\
\hline
\end{tabular}

Notes: Values in bracket represent standard errors in parentheses.

${ }^{* * *} p<0.01,{ }^{* *} p<0.05,{ }^{*} p<0.10$.

Next, Table 4 reports the findings of the system-GMM estimations for the four models. The main difference between the four models is the use of variables as a proxy of the ageing population. Two models used the old-age dependency ratio to the working-age population (age2), while the third and the fourth models used the ratio of population aged 65 and above against the total population (age1). Moreover, since rev and ge possess high correlation values, each of the ageing population proxies analyzed these two variables independently.

On the other hand, the lagged dependent variable (l.edebt) was found to be positive and highly significant for all four models. Consistent with the previous research, the significance implied that the level of current external debt for the UMIE is highly related to the past value of the external debt (Benfratello et al., 2018). The coefficient values for all four models fell 
within the range of 0.73 to 0.75 , further illustrating that the past amount of external debt leads to an even higher level of current external debt in the UMIE. Therefore, the UMIE's are required to acquire additional funds to boost the economy and to repay previous debts.

In addition, the need for a higher level of funding among the UMIE is further supported by considering the significant value of the domestic debt (debt) as another independent variable. The coefficient of the debt variable indicates a meaningful positive relationship with the level of external debt. It signifies that the UMIE requires massive funds for their economic development agenda. If the domestic debt level increases, the external debt level is also expected to increase but at a minimal rate. Thence, UMIE heavily relies on domestic debt compared to the external debt as a possible source of funding.

Referring to the variables under investigation, the ageing population generated a significantly positive relationship with UMIE's external debt, but at a very minimal impact (in between 0.058 percent to 0.063 percent). This relationship emerged when the population age of 65 and above was used as a proxy to represent the older population (in model 3 and 4). Meanwhile, when the old-age dependency ratio was used as a proxy of the ageing population, this variable possessed no significant relationship with the level of the external debt (as shown in model 1 and 2). Indirectly, the use of both proxies instigated that the ageing population may or may not be able to influence the external debt of the UMIE. This finding illustrates that the public debt theory by Barro (1979) and Mensah (2017) is not necessarily true in the case of UMIE. An increase in the population of age 65 and above gives pressure for the government to incur higher external debts as the needs for funds increase. This is in-line with the theory that stresses the uses of funds as one of the determinants of public debt. Nevertheless, when the proxy of ageing population is changed into the old-age dependency ratio, the public debt theory is no longer applicable. Probably, it is due to the fact that the elder people are not depending too much on the government. Instead, their burden is transferred to their children or relatives. Thus, the needs of funds do not change even when the old-age dependency ratio increases.

Empirically, a larger population of 65 years of age and above increases the external debt level due to the needs of the governments to inject more funds into healthcare industry, age-friendly infrastructure, retirement benefits and social security (Carbonaro et al., 2018; Horioka et al., 2018; Miranda, 2018; Mao, et al., 2020). Hence, the government may have to sacrifice the development projects due to limited revenues. Consequently, there might be a slowdown in the economic growth as postulated in the theory of secular stagnation since the government have to borrow money to finance their operating expenditure due to an increase in the number of ageing population. If they insist on injecting funds for the development projects, which are essential for economic growth, the governments will have to borrow more funds from the local and external sources.

Nevertheless, the current trend exhibited that most of the elderly citizens have received proper education in their previous years (Croix \& Licandro, 1999; Soong, 2020). Their level of literacy signified no significant influence of the old-age dependency ratio on the level of the external debt of the UMIE. The dependency is not a problem since older people have their savings to survive in their remaining life (Hillman, 2003). Even though the savings are expected to deteriorate over time, older people can still depend on their children. This is consistent 
with the theory of intergenerational social contract (Hillman, 2003), in which the children are responsible in taking care of their parents when their parents are no longer working. Hence, the governments are not pressurized to borrow more funds externally in these circumstances.

Of the seven control variables, rev was the only variable that had an insignificant relationship with external debt. As for the other control variables, ge, int and inv were capable of significantly influencing the external debt in a positive direction. Consistent with Barro (1979) and Mensah et al. (2017), the government will be forced to secure more funds if their level of expenditure increases over time. In this circumstance, imposing a higher level of taxation is not a wise decision as it will only distort the economic growth of a country. Secondly, higher external debt is expected as the interest rate on external debt increases. This finding contradicts with previous literature which found the relationship to be negative (Benfratello et al., 2018; Pirtea \& Nicolescu, 2012; Waheed, 2017). One of the possible reasons for the finding is due to the needs of the government to pay a higher amount of interest when the interest rate increases. Thirdly, the investment may or may not give a significant favourable influence on the level of the external debt. If it is significant, the level of significance is not too strong, especially for model 1 and 4. Despite the significant investment level, countries within the UMIE are not able to fully reap the benefits from the investment (Waheed, 2017). Instead, leads to a higher dependency on external debt. To the contrary, the result can also be insignificant as illustrated in model 3, consistent with the previous finding (Sadik-Zada \& Gatto, 2019).

The remaining control variables ( $s a v$, inf and $r g d p$ ) exhibited a significant negative relationship with the level of the external debt. Parallel with the findings by Waheed (2017), an increase in the national savings will help to reduce the external debt but at a very minimum rate. The government can utilise the savings for national development projects without relying too much on external debt. Similarly, inf and $r g d p$ as the macroeconomic variables indicated a significant negative impact on the external debt of the UMIE. Furthermore, during inflation the public will begin to save their money for future consumption, thus leading to a lower level of current consumption (Hasanov \& Cherif, 2012; Tarek \& Ahmed, 2017).

Consequently, during the time of lower current consumption, the government may not be able to generate higher income. Therefore, external debt increases as a result of inflation. However, when the economy is good, dependency on external debt is expected to decline. In this regard, the economy that has more income does not need additional funding to grow the economy (Barro, 1979; Benfratello et al., 2018; Mensah et al., 2017; Waheed, 2017).

The results discussed above are only deemed valid if they meet the two main conditions. Firstly, the residuals should be free from second-order autocorrelation. Hence, the ArellanoBond $(\mathrm{AB})$ test was employed with the null hypothesis stating no autocorrelation in the residuals can be rejected at the $\mathrm{AR}(1)$ test, but not at the $\mathrm{AR}(2)$ test. This indicates that there is no second-order autocorrelation exists in the residuals. Even though the first-order autocorrelation exists in the residuals, the GMM estimator allows it to happen since the system GMM consists of both level and first difference variables (Arellano \& Bond, 1991). Secondly, the instruments should appear to be exogenous. By using the Hansen test, the instruments in the model were estimated to be valid and exogenous if the null hypothesis of over-identifying restrictions was not rejected. The outcomes show that the null hypothesis is failed to be rejected, thus the instruments used in the models are valid and exogenous. 


\section{Conclusions}

This study empirically investigated the impacts of the ageing population on the external debt of the UMIE. The study argued that the ageing population increases the burden of the government, thus pressuring the governments to borrow more external funds. The results in this study were based on the panel data analysis which employed the system GMM estimation for 36 countries within the UMIE from 2000 to 2017.

Based on the results, mixed results were yielded in which the ageing population may or may not affect the external debt of the UMIE. The effects of the ageing population on the external debt depended on the proxy used to measure the ageing population. From one perspective, a higher number of population aged 65 and above increased the burden of the government, thus leading to a higher level of external debt. The increase of the government's burden may come from the needs to spend more on healthcare, age-friendly infrastructure, pensions and social security. However, based on the other perspective, the old-age dependency ratio (another proxy of the ageing population) indicated no significant influence on the external debt of the UMIE. It is because the older generation in the UMIE consisted of educated pensioners who have enough savings for their future expenses. Hence, the dependency on the government is minimal where it does not impact the level of the external debt.

Several implications were derived from the results of this study. Firstly, the private sector should work together with the public sector in building age-friendly infrastructure to cater to the ageing population. It will help to reduce the government's burden as the country is approaching the era of the ageing population. Secondly, the government should encourage all labors to contribute a portion of their income for their health insurance and retirement days which also includes entrepreneurs who are running their own businesses. If everyone has subscribed to health insurance and savings for their retirement days, the government can slowly focus on productive expenditures. In turn, it will also reduce the level of external debt which might harm the economic growth of a country.

This study is only focusing on how the ageing population affects the external debt of the UMIE. It does not consider the role of the ageing population on the domestic debt level. Hence, more rooms remain for future research as the increase in the ageing population might also give extra burden for the domestic debt.

For future research, we suggest forthcoming studies to examine the impact of the ageing population on the domestic debt level. It is because the ageing population is expected to increase the burden of the government, hence might increase the domestic debt level. An increase in the debt level may harm the economic growth of a country if the government fails to manage their funds well.

\section{Funding}

This study was funded by 2020 Teja's Internal Grant Scheme by Universiti Teknologi MARA, Melaka, Malaysia. 


\section{References}

Alonso-García, J., \& Rosado-Cebrian, B. (2019). Financial crisis and pension reform in Spain: The effect of labour market dynamics. Journal of Economic Policy Reform, 1-18. https://doi.org/10.1080/17487870.2019.1599718

Arčabić, V., Tica, J., Lee, J., \& Sonora, R. J. (2018). Public debt and economic growth conundrum: Nonlinearity and inter-temporal relationship. Studies in Nonlinear Dynamics and Econometrics, 22(1), 1-20. https://doi.org/10.1515/snde-2016-0086

Arellano, M., \& Bond, S. (1991). Some tests of specification for panel data: Monte Carlo evidence and an application to employment equations. The Review of Economic Studies, 58(2), 277-297. https://doi.org/10.2307/2297968

Barro, R. J. (1979). On the determination of the public debt. Journal of Political Economy, 87(5, Part 1), 940-971. https://doi.org/10.1086/260807

Benfratello, L., Del Monte, A., \& Pennacchio, L. (2018). Corruption and public debt: A cross-country analysis. Applied Economics Letters, 25(5), 340-344. https://doi.org/10.1080/13504851.2017.1321831

Blundell, R., \& Bond, S. (1998). Initial conditions and moment restrictions in dynamic panel data models. Journal of Econometrics, 87(1), 115-143. https://doi.org/10.1016/S0304-4076(98)00009-8

Carbonaro, G., Leanza, E., McCann, P., \& Medda, F. (2018). Demographic decline, population aging, and modern financial approaches to urban policy. International Regional Science Review, 41(2), 210-232. https://doi.org/10.1177/0160017616675916

Caruso, R., \& Domizio, M. Di. (2017). Military spending and budget deficits: The impact of US military spending on public debt in Europe. Defense and Peace Economics, 28(5), 534-549. https://doi.org/10.1080/10242694.2016.1228259

Croix, D. de la, \& Licandro, O. (1999). Life expectancy and endogenous growth. Economics Letters, 65(2), 255-263. https://doi.org/10.1016/S0165-1765(99)00139-1

Fu, L., Wang, Y., \& He, L. (2020). Age composition change and inter-provincial labor productivity: A study from the perspective of population dividend and population urbanization. Journal of Applied Economics, 23(1), 183-198. https://doi.org/10.1080/15140326.2020.1723885

Ghosh, A., \& Ghosh, C. (2008). Economics of the public sector. Prentice-Hall of India Private Limited.

Goedl, M., \& Zwick, C. (2018). Assessing the stochastic stability of public debt: The case of Austria. Empirica, 45, 559-585. https://doi.org/10.1007/s10663-017-9376-4

Hansen, L. (1982). Large sample properties of generalized method of moments estimators. Econometrica, 50(4), 1029-1054. https://doi.org/10.2307/1912775

Hasanov, F., \& Cherif, R. (2012). Public debt dynamics: The effects of austerity, inflation and growth shocks (IMF Working Paper No. 12/230). International Monetary Fund. https://www.imf.org/en/ Publications/WP/Issues/2016/12/31/Public-Debt-Dynamics-The-Effects-of-Austerity-Inflationand-Growth-Shocks-26268

Hillman, A. L. (2003). Public finance and public policy: Responsibilities and limitations of government. Cambridge University Press.

Horioka, C. Y., Morgan, P. J., Niimi, Y., \& Wan, G. (2018). Aging in Asia: Introduction to symposium. Review of Development Economics, 22(3), 879-884. https://doi.org/10.1111/rode.12545

Jackson, T. (2019). The post-growth challenge: Secular stagnation, inequality and the limits to growth. Ecological Economics, 156, 236-246. https://doi.org/10.1016/j.ecolecon.2018.10.010

Kim, E., Ha, Y., \& Kim, S. (2017). Public debt, corruption and sustainable economic growth. Sustainability, 9(3), 433. https://doi.org/10.3390/su9030433

Law, S. H. (2018). Applied panel data analysis: Short panels. UPM Press. 
Mao, G., Lu, F., Fan, X., \& Wu, D. (2020). China's ageing population: The present situation and prospects. In Population change and impacts in Asia and the Pacific (pp. 269-287). Springer.

Mensah, D., Aboagye, A. Q. Q., Abor, J. Y., \& Kyereboah-Coleman, A. (2017). External debt among HIPCs in Africa: Accounting and panel VAR analysis of some determinants. Journal of Economic Studies, 44(3), 431-455. https://doi.org/10.1108/JES-05-2015-0080

Miranda, A. E. R. (2018). Finding opportunities in Japan's aging population. CIRSS Commentaries, $5(7), 5-7$.

Mohd Daud, S. N., \& Podivinsky, J. M. (2012). Revisiting the role of external debt in economic growth of developing countries. Journal of Business Economics and Management, 13(5), 968-993. https://doi.org/ 10.3846/16111699.2012.701224

Ono, T., \& Uchida, Y. (2018). Human capital, public debt, and economic growth: A political economy analysis. Journal of Macroeconomics, 57, 1-14. https://doi.org/10.1016/j.jmacro.2018.03.003

Pirtea, M. G., \& Nicolescu, A. C. (2012). An empirical study on public debt's determinants: Evidence from Romania. Transylvanian Review of Administrative Sciences, 9(38), 144-157.

Poghosyan, T. (2018). How do financial cycles affect public debt cycles? Empirical Economics, 54(2), 425-460. https://doi.org/10.1007/s00181-016-1215-0

Reinhart, C. M., Reinhart, V. R., \& Rogoff, K. S. (2012). Public debt overhangs: Advanced-economy episodes since 1800. Journal of Economic Perspectives, 26(3), 69-86. https://doi.org/10.1257/jep.26.3.69

Sadik-Zada, E. R., \& Gatto, A. (2019). Determinants of the public debt and the role of the natural resources: A cross-country analysis (FEEM Working Paper No. 4). https://papers.ssrn.com/sol3/papers. cfm?abstract_id=3364174

Shkolnyk, I., \& Koilo, V. (2018). The relationship between external debt and economic growth: Empirical evidence from Ukraine and other emerging economies. Investment Management and Financial Innovations, 15(1), 387-400. https://doi.org/10.21511/imfi.15(1).2018.32

Soong, J. J. (2020). Empowering the elderly to promote active ageing in the labour market: A New strategic scheme to improve ageing human resource and to solve shortage of labour force in Taiwan. Jebat: Malaysian Journal of History, Politics \& Strategic Studies, 47(1).

Tarek, B. A., \& Ahmed, Z. (2017). Governance and public debt accumulation: Quantitative analysis in MENA countries. Economic Analysis and Policy, 56, 1-13. https://doi.org/10.1016/j.eap.2017.06.004

The World Bank Group. (2018). Data catalog: World development indicators. https://datacatalog.worldbank.org/dataset/world-development-indicators

Waheed, A. (2017). Determinants of external debt: A panel data analysis for oil and gas exporting and importing countries. International Journal of Economics and Financial Issues, 7(1), 234-240. 


\section{APPENDIX}

List of upper-middle-income economies:

\begin{tabular}{|c|c|c|c|}
\hline Included & $\begin{array}{l}\text { 1. Albania } \\
\text { 2. Algeria } \\
\text { 3. Armenia } \\
\text { 4. Azerbaijan } \\
\text { 5. Belarus } \\
\text { 6. Belize } \\
\text { 7. Bosnia and Herzegovina } \\
\text { 8. Botswana } \\
\text { 9. Brazil } \\
\text { 10. Bulgaria } \\
\text { 11. China } \\
\text { 12. } \text { Colombia }\end{array}$ & $\begin{array}{l}\text { 13. Costa Rica } \\
\text { 14. Dominican Republic } \\
\text { 15. Ecuador } \\
\text { 16. Fiji } \\
\text { 17. Gabon } \\
\text { 18. Guatemala } \\
\text { 19. Guyana } \\
\text { 20. Islamic Republic of Iran } \\
\text { 21. Jamaica } \\
\text { 22. Jordan } \\
\text { 23. Kazakhstan } \\
\text { 24. Malaysia }\end{array}$ & $\begin{array}{l}\text { 25. Mauritius } \\
\text { 26. Mexico } \\
\text { 27. Montenegro } \\
\text { 28. Paraguay } \\
\text { 29. Peru } \\
\text { 30. Romania } \\
\text { 31. Russian Federation } \\
\text { 32. Serbia } \\
\text { 33. South Africa } \\
\text { 34. Thailand } \\
\text { 35. Turkey } \\
\text { 36. Venezuela }\end{array}$ \\
\hline $\begin{array}{l}\text { Excluded } \\
\text { due to data } \\
\text { unavailability }\end{array}$ & $\begin{array}{ll}\text { 1. } & \text { American Samoa } \\
\text { 2. } & \text { Cuba } \\
\text { 3. } & \text { Dominica } \\
\text { 4. } & \text { Equatorial Guinea } \\
\text { 5. } & \text { Grenada } \\
\text { 6. } & \text { Macedonia }\end{array}$ & $\begin{array}{l}\text { 7. Lebanon } \\
\text { 8. Libya } \\
\text { 9. Iraq } \\
\text { 10. Marshall Islands } \\
\text { 11. Namibia } \\
\text { 12. Nauru } \\
\text { 13. Maldives }\end{array}$ & $\begin{array}{l}\text { 14. Samoa } \\
\text { 15. St. Lucia } \\
\text { 16. St Vincent and the } \\
\text { Grenadines } \\
\text { 17. Suriname } \\
\text { 18. Tonga } \\
\text { 19. Turkmenistan } \\
\text { 20. Tuvalu }\end{array}$ \\
\hline
\end{tabular}

\section{Notations}

\section{Abbreviations}

AGE1 - Ratio of population ages 65 and above against total population;

AGE2 - Ratio of old age dependency ratio against working-age population;

DEBT - General government gross debt as a percentage of GDP;

EDEBT - External debt stocks to GNI;

FE - Fixed effect;

GDP - Gross Domestic Product;

GE - - General government total expenditure as a percentage of GDP;

GMM - Generalised Method of Moments;

INF - Annual percentage of inflation based on consumer prices;

INT - Interest payments on external debt as a percentage of GNI;

INV - Gross capital formation as a percentage of GDP;

L.EDEBT - Lag of external debt stocks to GNI;

POLS - Pooled Ordinary Least Square;

RE - Random effect;

REV - General government revenue as a percentage of GDP;

RGDP - Annual growth of real GDP;

SAV - Gross domestic savings as a percentage of GDP;

UMIE - upper-middle-income economies. 